\title{
RAPID VERMICOMPOSTING OF FRESH FRUIT AND VEGETABLE WASTES USING EARTHWORM EISENIA FOETIDA
}

\author{
Kui HUANG ${ }^{*}$, Fusheng LI $^{2 *}$, Jiefeng LI $^{1}$, Denny HELARD ${ }^{1}$, and Kayako HIROOKA ${ }^{2}$ \\ ${ }^{1}$ Graduate School of Engineering, Gifu University \\ (1-1 Yanagido, Gifu 501-1193, Japan) \\ ${ }^{2}$ River Basin Research Center, Gifu University \\ (1-1 Yanagido, Gifu 501-1193, Japan) \\ *E-mail: lifs@gifu-u.ac.jp (for Fusheng LI), q3812102@edu.gifu-u.ac.jp (for Kui HUANG)
}

\begin{abstract}
The aim of this study was to evaluate the feasibility of rapid vermicomposting of different fresh fruit and vegetable wastes (FVWs) including banana peels, cabbage, lettuce, potato and watermelon peels using earthworm Eisenia foetida. For this, the changes of physicochemical properties, microbial profiles and earthworm biology were comprehensively evaluated after vermicomposting for 4 weeks. Compared to controls (without earthworms), vermicomposting caused reductions of the total carbon content by $42.7-52.4 \%$ and the carbon to nitrogen ratios by $46.5-61.1 \%$, and increases of the electrical conductivity by $6.7-69.4 \%$ and the total phosphorous content by $4.0-52.0 \%$. Vermicomposting revealed a higher microbial activity, density and diversity in end products than controls. The vermicomposting treatment for FVWs allowed a high growth rate of earthworms and an increased number of cocoons. Similar microbial community structures were observed in all vermicomposts, indicating a high degree of bio-stabilization and maturity. The results suggest that rapid vermicomposting is a feasible technology for converting fresh FVWs into valuable products and that the quality of vermicomposts is strongly associated with the properties of initial substrates.
\end{abstract}

Key Words: vermicomposting, earthworm, fruit and vegetable waste, real time qPCR, PCR-DGGE

\section{INTRODUCTION}

Large amounts of fruit and vegetable wastes (FVWs) are produced in food processing factories and supermarkets, constituting a source of nuisance in the incineration plant due to their high water content. However, their high biodegradability and low toxicity make them suitable for reuse in the green industry where the valuable nutrients are recycled and converted into new products. Vermicomposting using earthworms is a sustainable, cost-effective and ecological technology for efficient management of the biodegradable wastes, and widely applied to recycle hazardous and worthless organic wastes into safe and valuable products ${ }^{1)}$. Vermicomposting is a process of biochemical degradation of organic materials by earthworms and microorganisms. Although microorganisms participate in decomposition of organic matter, earthworms act as a critical driver of this process by comminuting the organic matter, increasing the area of aerobic microbial activity and triggering the enzymatic activity, thus stimulating the decomposition further ${ }^{2}$. FVWs such as mushroom wastes $^{3)}$, pineapple wastes ${ }^{4)}$, tomato wastes $^{5)}$, grape $\operatorname{marc}^{(6)}$ and vegetable mixture ${ }^{7-9)}$ are considered to be important nutrient sources and can be treated by this technology. Since the compositions of FVWs are complex and vary depending on the lifestyle and eating habits of consumers, to determine and elevate the efficiency of vermicomposting for FVWs and clarify the mechanisms involved, systematical and intensive investigations are desired. In addition, to date, limited study has been attempted to investigate the potential of vermicomposting for such FVW species as banana peels, cabbage, lettuce, potato and water melon peels, which constitute for a major part of organic waste even from households.

Conventional vermicomposting requires a preliminary treatment to dry fresh FVWs for one to three weeks ${ }^{3-9)}$ because earthworms cannot survive 
in the feed materials with high-content of water. This not only increases the whole time needed for vermicomposting but also requires energy. In addition, the pretreatment also leads to the loss of considerable amounts of nutrients via leachate. Approaches that can improve the conventional vermicomposting process are desired. Generally, vermicomposting product (also called as vermicompost) has larger porosity, higher water-holding capacity and higher microbial activity. It may serve as an effective bedding material for earthworms, and vermicomposting reactors installed with a bedding space of vermicompost can probably hold water from fresh FVWs and hence enable omitting of the pretreatment of drying needed in the conventional vermicomposting process. Literature review showed there had been little research work using vermicompost as the bedding material for earthworms functioning in the vermicomposting process for fresh FVWs.

Microbial population and structure are important indicators to evaluate the maturity of composting and vermicomposting ${ }^{10-11)}$. Previous studies that determined the microbial population and structure in organic composts were mostly based on conventional cultivation methods ${ }^{12-14}$, by which however, non-culturable microorganisms cannot be detected. Recent studies have reported that real time quantitative PCR (qPCR) and denaturing gradient gel electrophoresis (DGGE) of PCR-amplified 16S rRNA gene fragments are fast and reliable techniques to precisely reveal bacterial population and their genetic fingerprints in environment ${ }^{10)}$. However, there are only a few studies that evaluated the maturity of microbial community in the vermicomposting system with the techniques.

Accordingly, the aim of this study was to evaluate the feasibility of using vermicompost as the vermibedding material to realize faster vermicomposting for fresh FVWs. For this, five types of fresh FVWs collected from a supermarket in Gifu, Japan, were subjected to vermicomposting experiments using Eisenia foetida (E. foetida) as the earthworm species. Chemical and biochemical changes of FVWs during vermicomposting were evaluated. Moreover, to examine the impact of earthworms on the bacterial genetic structure and the degree of stabilization, analyses with qPCR and PCR-DGGE were carried out for the vermicomposts.

\section{METHODS}

\section{(1) Experimental setup}

Non-clitellated E. foetida species were randomly selected from the stock culture in the laboratory. The fresh FVWs chosen for this study included banana peels $(\mathrm{B})$, cabbage $(\mathrm{C})$, lettuce $(\mathrm{L})$, potato $(\mathrm{P})$ and watermelon peels (W), all of which were obtained from Kanesue, a supermarket in Gifu, Japan. Some physicochemical characteristics of the FVWs are summarized in Table 1.

Vermicomposting of FVWs was conducted in mesocosms that consisted of perforated plastic containers each having a size of $245 \mathrm{~cm} \times 355 \mathrm{~cm} \times$ $140 \mathrm{~cm}$. Each container consisted of two layers. The bottom layer was filled with vermicompost obtained in a preparatory experiment to provide a comfortable bed for earthworms. The top layer was supplied with the individual organic waste to be treated. Between the two layers, a plastic mesh with an opening about $30 \mathrm{~mm} \times 30 \mathrm{~mm}$ was placed to avoid mixing of FVWs with the bedding material and to facilitate the removal of FVWs after processed by earthworms. For each reactor 200 juvenile earthworms randomly collected from the stock culture were accommodated in the layer of the bedding material. Above the plastic mesh, $1 \mathrm{~kg}$ of fresh FVW after being chopped was added and wetted by spraying $50 \mathrm{ml}$ of tap water. All reactors were covered with a wet tower to keep the moisture at about $70-80 \%$, and operated under a controlled temperature condition $\left(25 \pm 2^{\circ} \mathrm{C}\right)$. For comparison, control experiment for each vegetable and fruit peel in the absence of earthworms was also performed. Three reactors were operated in parallel for vermicomposting treatment of each type of FVWs.

After vermicomposting for 28 days, earthworms and their cocoons were removed by hand from each reactor. The resulting vermicompost was homogenized and divided into two subsamples. One was dried and finely pulverized for chemical analysis and another one was stored at $-20^{\circ} \mathrm{C}$ for enzyme activity and DNA analysis.

\section{(2) Chemical and dehydrogenase activity analysis}

The $\mathrm{pH}$ value and electrical conductivity were measured in a solution by mixing the sample with water (dry weight of sample/weight of water = 1/10). Total carbon and total nitrogen were analyzed by an elemental analyzer (Yanaco CHN CORDER MT-6, Japan). Total phosphorus was measured using the molybdenum blue-absorption method (at $880 \mathrm{~nm}$ ). Total microbial activity was determined by measuring dehydrogenase activity (DA) with the triphenyl-tetrazolium chloride method. 
Table 1 Physicochemical properties of the fruit and vegetable wastes used

\begin{tabular}{ccccccc}
\hline Waste type & $\begin{array}{c}\text { Water } \\
\text { content } \\
(\%)\end{array}$ & $\mathrm{pH}$ & $\begin{array}{c}\text { Electrical } \\
\text { conductivity } \\
(\mathrm{ds} / \mathrm{m})\end{array}$ & $\begin{array}{c}\text { Total carbon } \\
(\mathrm{g} / \mathrm{kg})\end{array}$ & $\begin{array}{c}\text { Total nitrogen } \\
(\mathrm{g} / \mathrm{kg})\end{array}$ & $\begin{array}{c}\text { Total } \\
\text { phosphorus } \\
(\mathrm{g} / \mathrm{kg})\end{array}$ \\
\hline Banana & 87.5 & 4.97 & 5.59 & 318.0 & 6.6 & 3.4 \\
peels & $(87.3 \sim 87.6)$ & $(4.95 \sim 5.00)$ & $(5.55 \sim 5.66)$ & $(307.9 \sim 331.0)$ & $(6.6 \sim 6.6)$ & $(3.2 \sim 3.5)$ \\
Cabbage & 93.3 & 5.02 & 2.27 & 324.4 & 13.4 & 3.1 \\
& $(92.8 \sim 94.0)$ & $(4.99 \sim 5.09)$ & $(2.23 \sim 2.29)$ & $(319.4 \sim 327.4)$ & $(13.3 \sim 13.5)$ & $(3.0 \sim 3.2)$ \\
Lettuce & 91.6 & 5.31 & 3.02 & 313.7 & 21.6 & 2.7 \\
Potato & $(89.9 \sim 92.1)$ & $(5.27 \sim 5.35)$ & $(2.67 \sim 3.40)$ & $(311.2 \sim 317.9)$ & $(21.0 \sim 22.4)$ & $(2.4 \sim 2.9)$ \\
Watermelon & 77.5 & 6.18 & 1.35 & 247.7 & 9.97 & 3.9 \\
peels & $(76.6 \sim 78.8)$ & $(6.17 \sim 6.20)$ & $(1.32 \sim 1.40)$ & $(235.0 \sim 265.5)$ & $(9.50 \sim 1.04)$ & $(3.7 \sim 4.3)$ \\
\hline
\end{tabular}

Data are mean values of three replicates. The values given in parentheses show the range from minimum to maximum.

\section{(3) DNA extraction and PCR-DGGE analysis}

$250 \mathrm{mg}$ of the subsample of each vermicomposting product was subjected to DNA extraction using the MoBio UltraClean Soil DNA Isolation kit (MO BIO Laboratories, Inc., Carlsbad, CA, USA), following the manufacturer's protocol.The primers GC341F (5',-CGC CCG CCG CGC GCG GCG GGC GGG GCG GGG CAC GGG GGG CCT ACG GGA GGC AGC AG-3') and 907R (5'-CCG TCA ATT CCT TTG AGT TT-3') were used to amplify the fragment. PCR reactions were performed by adding $1 \mu$ of each DNA extract to a total volume of $50 \mu \mathrm{l}$ containing $20 \mu \mathrm{M}$ each primer $(0.5 \mu \mathrm{l}), 10 \times \mathrm{Ex}$ Taq buffer $(5 \mu \mathrm{l}), 2.5 \mathrm{mM}$ dNTPs $(4 \mu \mathrm{l}), 0.1 \%$ bovine serum albumin (BSA) (1 $\mu \mathrm{l}), 250 \mu \mathrm{M}$ Ex Taq enzyme $(0.25 \mu \mathrm{l})$ and sterilized pure water $(37.75 \mu \mathrm{l})$. A non-template control, containing all PCR components except DNA extract, was included in parallel. The PCR program initiated by denaturation at $95{ }^{\circ} \mathrm{C}$ for $5 \mathrm{~min}$, followed by 35 amplification cycles of $30 \mathrm{~s}$ at $95^{\circ} \mathrm{C}$, $30 \mathrm{~s}$ at $57^{\circ} \mathrm{C}$ and $40 \mathrm{~s}$ at $72{ }^{\circ} \mathrm{C}$, and finally by an extension step for $10 \mathrm{~min}$ at $72{ }^{\circ} \mathrm{C}$. The PCR products were first tested by electrophoresis in $1.5 \%$ agarose gels stained with ethidium bromide.

DGGE was conducted by loading about $100 \mathrm{ng}$ of each PCR product into $7 \%(\mathrm{w} / \mathrm{v})$ polyacrylamide gel with a denaturing gradient of 40-65\% (100\% denaturant contains $7 \mathrm{M}$ urea plus $40 \%$ formamide in 1×TAE buffer (20 mM Tris, $10 \mathrm{mM}$ acetate, 0.5 $\mathrm{mM} \mathrm{Na} \mathrm{N}_{2}$ EDTA)) and then running for $800 \mathrm{~min}$ at $100 \mathrm{~V}$ and a constant temperature of $60{ }^{\circ} \mathrm{C}$ in $1 \times$ TAE buffer using an BIO-RAD Dcode ${ }^{\mathrm{TM}}$ system (Bio-Rad, USA). Subsequently, the gel was strained for $20 \mathrm{~min}$ in $1 \times \mathrm{TAE}$ buffer containing a 1:10,000 dilution of $\mathrm{SYBR}^{\circledR}$ Green Nucleic Acid Gel Stain (TAKARA) and visualized with the Gel Doc 2000 System (Bio-Rad, USA).

\section{(4) Real-time qPCR assay}

The universal primers specific for V4-V5 hypervariable region of $16 \mathrm{~S}$ rDNA, com1 (5'-CAGCAGCCGCGGTAATAC-3') and com2 (5'-CCGTCAATTCCTTTGAGTTT-3'), were used for quantifying the number of $16 \mathrm{~S}$ rDNA copies. PCR reactions were preformed in a $25 \mu \mathrm{l}$ volume containing $2 \mu \mathrm{l}$ of DNA extract, $12.5 \mu \mathrm{l}$ of SYBR Ex Taq (TAKARA), $0.5 \mu \mathrm{l}$ each primer $(0.4 \mu \mathrm{M})$ and $9.5 \mu \mathrm{l}$ of sterilized pure water. Three replicates for each extracted DNA were included. The real-time qPCR program consisted of initial denaturation at $95{ }^{\circ} \mathrm{C}$ for $5 \mathrm{~min}$ followed by 35 three-step cycles of $95{ }^{\circ} \mathrm{C}$ for $15 \mathrm{~s}, 60^{\circ} \mathrm{C}$ for $30 \mathrm{~s}$, and $72{ }^{\circ} \mathrm{C}$ for $30 \mathrm{~s}$. All experiments included negative (without target DNA) and serial dilutions of an E. coli DNA standard. DNA amplification and quantification were performed with a real time PCR system (Thermal Cycler Dice, TP800, TAKARA).

Absolute quantification of DNA in qPCR was accomplished using the standard curves of known concentrations of DNA of E. coli. In this study, standard curves were generated using 1:10x serial dilutions of $E$. coli over seven orders of magnitude and plotted as the log of DNA concentration versus the threshold cycle $(\mathrm{Ct})$ value.

\section{(5) Data analyses}

Significant differences in the means of parameters between the control and vermicomposting treatments were tested based on one-way analysis of variance (ANOVA) with mean separation by Tukey's significant difference (HSD) test at $95 \%$ confidence level using the software of STATISTIC 8.0. Digitalized DGGE fingerprints were analyzed using the Quantity One image analysis software v.4.2 (Bio-Rad Laboratories, Hercules, CA, USA) to compute a similarity matrix using the Dice's coefficient to generate an UPGMA (unweighted pair group method with arithmetic averages) dendrogram. The Shannon index of the 
general diversity $H$ was calculated from the following equations:

$$
H=\sum\left\{\left(\frac{N_{i}}{N}\right) \ln \left(\frac{N_{i}}{N}\right)\right\}
$$

where $N_{i}$ is the height of the peak of the band $i$ and $N$ is the sum of all peak heights in the targeted lane of the obtained DGGE profile.

\section{RESULTS AND DISCUSSION}

\section{(1) Physicochemical properties of FVWs during vermicomposting}

After vermicomposting for 4 weeks, the end products showed a finely granular appearance. The average water content of banana peels, cabbage, lettuce, potato and watermelon peels in end products was $77.1 \%, 65.7 \%, 57.6 \%, 72.0 \%$ and $58.4 \%$, respectively, which is less than the water content of raw materials (Table 1). As shown in Table 2, vermicomposting significantly modified the physicochemical properties of FVWs. The $\mathrm{pH}$ values detected in the vermireactors significantly increased as compared to those in the control reactors, except for the watermelon peels treatment. The changes in $\mathrm{pH}$ are attributed to the degradation of organic matter and the formation of intermediate products such as ammonium ions and humic acids during the vermicomposting process ${ }^{7}$. Moreover, it was reported that different substrates can cause the production of dissimilar intermediate species, which resulted in different behaviors in $\mathrm{pH}$ shift ${ }^{1)}$.

Table 2 Chemical properties of the end vermicomposts and controls

\begin{tabular}{|c|c|c|c|c|c|c|}
\hline \multirow{2}{*}{ Waste type } & \multicolumn{2}{|c|}{$\mathrm{pH}$} & \multirow[b]{2}{*}{$t$-Test } & \multicolumn{2}{|c|}{ Electrical conductivity (dS/m) } & \multirow[b]{2}{*}{$t$-Test } \\
\hline & Vermicompost & Control & & Vermicompost & Control & \\
\hline Banana peels & $\begin{array}{c}9.04 \\
(9.01 \sim 9.11)\end{array}$ & $\begin{array}{c}8.75 \\
(8.73 \sim 8.76)\end{array}$ & $0.01 *$ & $\begin{array}{c}7.11 \\
(6.97 \sim 7.32)\end{array}$ & $\begin{array}{c}5.27 \\
(5.21 \sim 5.35)\end{array}$ & $0.00 *$ \\
\hline Cabbage & $\begin{array}{c}8.23 \\
(8.18 \sim 8.30)\end{array}$ & $\begin{array}{c}7.25 \\
(7.23 \sim 7.27)\end{array}$ & $0.00 *$ & $\begin{array}{c}3.84 \\
(3.75 \sim 3.89)\end{array}$ & $\begin{array}{c}3.06 \\
(3.01 \sim 3.09)\end{array}$ & $0.00 *$ \\
\hline Lettuce & $\begin{array}{c}8.52 \\
(8.50 \sim 8.54)\end{array}$ & $\begin{array}{c}8.25 \\
(8.21 \sim 8.28)\end{array}$ & $0.00 *$ & $\begin{array}{c}2.60 \\
(2.58 \sim 2.64)\end{array}$ & $\begin{array}{c}2.53 \\
(2.48 \sim 2.64)\end{array}$ & 0.28 \\
\hline Potato & $\begin{array}{c}8.13 \\
(8.03 \sim 8.25)\end{array}$ & $\begin{array}{c}7.29 \\
(7.28 \sim 7.31)\end{array}$ & $0.00 *$ & $\begin{array}{c}2.71 \\
(2.59 \sim 2.88)\end{array}$ & $\begin{array}{c}1.60 \\
(1.58 \sim 1.65)\end{array}$ & $0.00 *$ \\
\hline \multirow[t]{3}{*}{$\begin{array}{c}\text { Watermelon } \\
\text { peels }\end{array}$} & $\begin{array}{c}8.37 \\
(8.36 \sim 8.38)\end{array}$ & $\begin{array}{c}9.04 \\
(8.96 \sim 9.08)\end{array}$ & $0.00 *$ & $\begin{array}{c}2.39 \\
(2.30 \sim 2.49)\end{array}$ & $\begin{array}{c}2.24 \\
(2.19 \sim 2.30)\end{array}$ & 0.08 \\
\hline & \multicolumn{2}{|c|}{ Total carbon $(\mathrm{g} / \mathrm{kg})$} & & \multicolumn{2}{|c|}{ Carbon to nitrogen ratio } & \\
\hline & Vermicompost & Control & $t$-Test & Vermicompost & Control & $t$-Test \\
\hline Banana peels & $\begin{array}{c}115.3 \\
(107.6 \sim 124.9)\end{array}$ & $\begin{array}{c}242.3 \\
(239.4 \sim 247.0)\end{array}$ & $0.00 *$ & $\begin{array}{c}16.2 \\
(15.2 \sim 17.1)\end{array}$ & $\begin{array}{c}41.6 \\
(38.9 \sim 43.5)\end{array}$ & $0.00 *$ \\
\hline Cabbage & $\begin{array}{c}83.3 \\
(81.9 \sim 84.4)\end{array}$ & $\begin{array}{c}175.1 \\
(171.4 \sim 182.1)\end{array}$ & $0.00 *$ & $\begin{array}{c}10.8 \\
(10.5 \sim 11.2)\end{array}$ & $\begin{array}{c}23.0 \\
(22.6 \sim 23.6)\end{array}$ & $0.00 *$ \\
\hline Lettuce & $\begin{array}{c}79.9 \\
(78.3 \sim 82.8)\end{array}$ & $\begin{array}{c}146.2 \\
(146.1 \sim 146.4)\end{array}$ & $0.00 *$ & $\begin{array}{c}12.7 \\
(12.2 \sim 13.1)\end{array}$ & $\begin{array}{c}15.5 \\
(15.1 \sim 15.9)\end{array}$ & $0.00 *$ \\
\hline Potato & $\begin{array}{c}81.3 \\
(80.1 \sim 82.4)\end{array}$ & $\begin{array}{c}162.3 \\
(158.0 \sim 164.6)\end{array}$ & $0.00 *$ & $\begin{array}{c}10.8 \\
(10.8 \sim 10.8)\end{array}$ & $\begin{array}{c}26.0 \\
(25.4 \sim 26.8)\end{array}$ & $0.00 *$ \\
\hline \multirow[t]{3}{*}{$\begin{array}{l}\text { Watermelon } \\
\text { peels }\end{array}$} & $\begin{array}{c}70.1 \\
(67.7 \sim 74.4)\end{array}$ & $\begin{array}{c}126.7 \\
(126.1 \sim 127.3)\end{array}$ & $0.00 *$ & $\begin{array}{c}12.1 \\
(11.7 \sim 12.6)\end{array}$ & $\begin{array}{c}19.3 \\
(18.7 \sim 19.8)\end{array}$ & $0.00 *$ \\
\hline & \multicolumn{2}{|c|}{ Total nitrogen $(\mathrm{g} / \mathrm{kg})$} & & \multicolumn{2}{|c|}{ Total phosphorus $(\mathrm{g} / \mathrm{kg})$} & \\
\hline & Vermicompost & Control & $t$-Test & Vermicompost & Control & $t$-Test \\
\hline Banana peels & $\begin{array}{c}7.1 \\
(7.1 \sim 7.2)\end{array}$ & $\begin{array}{c}5.8 \\
(5.5 \sim 6.3)\end{array}$ & $0.00 *$ & $\begin{array}{c}4.4 \\
(4.3 \sim 4.5)\end{array}$ & $\begin{array}{c}3.3 \\
(3.0 \sim 3.4)\end{array}$ & $0.00 *$ \\
\hline Cabbage & $\begin{array}{c}7.7 \\
(7.5 \sim 7.8)\end{array}$ & $\begin{array}{c}7.6 \\
(7.5 \sim 7.8)\end{array}$ & 0.49 & $\begin{array}{c}4.1 \\
(4.0 \sim 4.2)\end{array}$ & $\begin{array}{c}2.9 \\
(2.8 \sim 3.3)\end{array}$ & $0.00 *$ \\
\hline Lettuce & $\begin{array}{c}6.3 \\
(6.2 \sim 6.4)\end{array}$ & $\begin{array}{c}9.4 \\
(9.2 \sim 9.7)\end{array}$ & $0.00 *$ & $\begin{array}{c}3.8 \\
(3.6 \sim 3.9)\end{array}$ & $\begin{array}{c}2.5 \\
(2.2 \sim 2.7)\end{array}$ & $0.00 *$ \\
\hline Potato & $\begin{array}{c}7.5 \\
(7.4 \sim 7.6)\end{array}$ & $\begin{array}{c}6.2 \\
(6.1 \sim 6.4)\end{array}$ & $0.00^{*}$ & $\begin{array}{c}4.6 \\
(4.4 \sim 4.7)\end{array}$ & $\begin{array}{c}3.7 \\
(3.6 \sim 3.7)\end{array}$ & $0.00 *$ \\
\hline $\begin{array}{l}\text { Watermelon } \\
\text { peels }\end{array}$ & $\begin{array}{c}5.8 \\
(5.5 \sim 6.0)\end{array}$ & $\begin{array}{c}6.6 \\
(6.4 \sim 6.8)\end{array}$ & $0.00 *$ & $\begin{array}{c}5.2 \\
(5.1 \sim 5.3)\end{array}$ & $\begin{array}{c}5.0 \\
(5.0 \sim 5.0)\end{array}$ & $0.03 *$ \\
\hline
\end{tabular}

Data are mean values of three replicates. The values given in parentheses show the range from minimum to maximum.

* means the observed difference is significant $(p<0.05)$. 
Similar results were also reported regarding the vermicomposting of mushroom wastes, vegetable wastes and tomato wastes ${ }^{3,5,7)}$. Substantial increases in the values of electrical conductivity were also observed in the final products of the vermireactors over the control reactors except for the lettuce treatment. The maximum increase of electrical conductivity $(69.4 \%)$ was obtained in the potato treatment with comparison to the control treatment. Such increase was possibly due to the loss of organic matter and the release of different mineral salts in available forms such as phosphate, ammonium and potassium ${ }^{15)}$.

For all the vermicomposting treatments, the total carbon content decreased by $63.7-78.3 \%$ as compared to the initial substrate, with the watermelon treatment enabling the largest total carbon reduction (Table 2). On the contrary, the control treatments allowed a smaller decrease in the total carbon content $(23.8-60.8 \%)$. The significant differences in the concentrations of carbon loss between the vermicomposting and control treatments suggest that the earthworms-mediated rapid organic matter mineralization occurs during vermicomposting. It was considered that the biological mutuality between earthworms and associated microbes in decomposing waste may lead to the carbon loss in the form of $\mathrm{CO}_{2}$ from the substrates ${ }^{16)}$. Conversion of some organic fraction of wastes into worm biomass may be another contributor to the carbon loss in the composting waste $^{16)}$. The watermelon peels treatment gives rise to a specific microbial community responsible for the high total carbon mineralization rate.

Compared to control treatments, the banana peels and potato treatments resulted in a remarkable increase in the total nitrogen content, but the lettuce and watermelon peels treatments showed significantly opposite trends and negligible change was observed for the cabbage treatment (Table 2). Such variations can be explained by the different production of leachate content, and the different amount of nitrogen required for earthworm growth during vermicomposting ${ }^{7)}$. Previous studies have reported that vermicomposting may enrich the nitrogen content due to the presence of earthworms containing mucus, enzymes and nitrogenous excretory substances which provided high levels of available nitrogen ${ }^{9,16)}$. Moreover, the increased microbial activity and the increased concentration of nitrogen-fixing bacteria as a consequence of the increasing earthworm activity were likely another important reason for the enhanced nitrogen content in the end products ${ }^{16}$. On the contrary, the denitrification process in the worm's digestive tract during vermicomposting contributed to the reduction in the nitrogen concentration ${ }^{17)}$.

As compared to control treatments, the total phosphorus content increased significantly for all the treatments in the presence of earthworms (increased by $4.0-52.0 \%$ ), but the extent of total phosphorus enhancement was highly relied on the initial phosphorous concentration contained in the specific substrate (Table 2). The increase in the total phosphorus content was in good agreement with the findings of other researchers ${ }^{1,7}$. This observation is likely due to mineralization and mobilization of phosphorous as a result of bacterial and fecal phosphates activity of earthworms ${ }^{1)}$.

The carbon to nitrogen ratio of FVWs markedly decreased to the values below 20 in all the vermireactors (Table 2). As comparison with control treatments, the carbon to nitrogen ratio decreased by $46.5-61.1 \%$, with the banana peels showing the maximum decrease. The carbon to nitrogen ratio was widely used as an index of maturity and stability. According to Morais and Queda $^{18)}$, the value less than 20 was indicative of acceptable maturity, and the ratio of 15 or lower was thought to be preferable for the agronomic fertilizer products. These findings suggest that a high degree of organic matter stabilization was achieved in all the reactors. However, it should be noted that this index provides only a rough estimation of the bio-stabilization and mature of end products, because some particular substrates containing a highly variable lignin:cellulose ratio or other recalcitrant components may have impacts on their biodegradability ${ }^{5)}$.

\section{(2) Earthworm growth rate and cocoon number during vermicomposting}
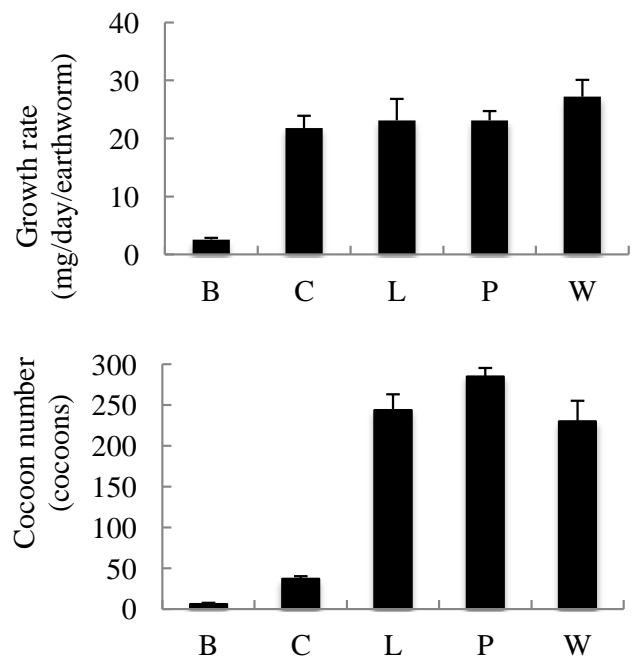

Fig. 1 The growth rate and cocoon production of earthworm in different types of waste. The letters of B, C, L, P and W represent banana peels, cabbage, lettuce, potato and watermelon peels, respectively. Error bars represent standard deviation. 
Figure 1 shows the growth rate of earthworms and the number of cocoons in all the vermireactors. The highest rate $(27.4 \mathrm{mg} /$ day/worm) was found in the watermelon peels treatment, and the lowest one (2.6 mg/day/worm) was observed in the banana peels treatment. These values are comparable to the findings related to earthworm growth in the vegetable waste spiked with biogas slurry (6.81 $\mathrm{mg} /$ day/worm $)^{9)}$ and the vegetable waste spiked with cow dung $(16.07 \mathrm{mg} / \text { day/worm })^{8)}$. The production of cocoons was also distinctly varied depending on the specific FVW, with the maximum and the minimum numbers recorded in the potato treatment and the banana peels treatment, respectively. The difference in the growth rate and cocoon production of earthworms is closely related to the quality of food sources (i.e., electrical conductivity, carbon to nitrogen ratio and $\mathrm{pH}$ ) and the inhabitation condition (i.e., temperature, and moisture content). The lowest value of growth rate and cocoons in the banana peels treatment may be partly caused by the high electrical conductivity and carbon to nitrogen ratio, as illustrated in Table 2. Similar results were also found by Aira et al, ${ }^{19)}$ that the earthworms cannot achieve a high growth rate and cocoon numbers if they live in a substrate with high carbon to nitrogen ratio. Gunadi and Edwards $^{20)}$ reported that E. foetida was unable to survive in the fresh fruits wastes (e.g. cucumber, pear, and apple) over 3 weeks due to their high electrical conductivity $(12.8 \mathrm{dS} / \mathrm{m})$. It should be noted that some food sources containing toxicants/accelerating regents to earthworms or microorganisms may also be responsible for the lower/higher biomass of earthworms.
(3) Microbial activity, density and diversity during vermicomposting

Dehydrogenase activity (DA) has been widely used to estimate the microbial activity in the composting process because an intracellular enzyme is involved in biologically oxidative phosphorylation ${ }^{5,7,10,11)}$. The higher DA value recorded in the vermicomposts indicated that the organic materials present in FVWs with earthworms were metabolized more actively than those without earthworms (Table 3). The increased DA compared to the control experiments is agreement with the findings of other studies ${ }^{11)}$, which demonstrated that vermicomposting can remove $95 \%$ of the total soluble phenolic compounds that inhibit the DA. The difference in DA for different FVWs is probably related to the different decomposition efficiencies of phenolic compounds during vermicomposting. In addition, the fresh casts excreted by earthworms are also responsible for the increased DA in the vermicomposts ${ }^{10}$.

As described in Table 3, bacterial numbers from the vermicomposting treatments were about $25-172$ times higher than those from the control treatments. Previous studies have also reported that the enhanced population of bacteria in the worm-worked substrates after vermicomposting ${ }^{11-13)}$. The increased bacterial numbers in the vermicomposts may be attributed to the gut of earthworms, which can lead to an increase in the number of vegetative cells as well as germination of the spores of this bacterial community ${ }^{14}$. Moreover, the priming effect triggered by earthworm's mucus is able to induce a lot of microbes and simultaneously enhance their activity after the gut transit process, as revealed in a recent report ${ }^{21)}$.

Table 3 Dehydrogenase activity and bacterial number of the end vermicomposts and controls

\begin{tabular}{|c|c|c|c|c|c|c|}
\hline \multirow[t]{2}{*}{ Waste type } & \multicolumn{2}{|c|}{$\begin{array}{c}\text { Dehydrogenase activity } \\
(\mu \mathrm{g} \mathrm{TPF} / \mathrm{g} / \mathrm{h})\end{array}$} & \multirow[b]{2}{*}{$t$-Test } & \multicolumn{2}{|c|}{$\begin{array}{l}\text { Bacterial number } \\
\left(\times 10^{8} \text { copies } / g\right)\end{array}$} & \multirow[b]{2}{*}{$t$-Test } \\
\hline & Vermicompost & Control & & Vermicompost & Control & \\
\hline Banana peels & $\begin{array}{c}19.0 \\
(16.4 \sim 21.3)\end{array}$ & $\begin{array}{c}5.7 \\
(4.4 \sim 6.7)\end{array}$ & $0.00 *$ & $\begin{array}{c}144 \\
(129 \sim 162)\end{array}$ & $\begin{array}{c}1.63 \\
(1.53 \sim 1.70)\end{array}$ & $0.00^{*}$ \\
\hline Cabbage & $\begin{array}{c}30.5 \\
(25.1 \sim 35.6)\end{array}$ & $\begin{array}{c}3.7 \\
(2.8 \sim 4.3)\end{array}$ & $0.00 *$ & $\begin{array}{c}97.2 \\
(83.7 \sim 110)\end{array}$ & $\begin{array}{c}3.87 \\
(3.45 \sim 4.11)\end{array}$ & $0.00 *$ \\
\hline Lettuce & $\begin{array}{c}28.8 \\
(25.2 \sim 32.7)\end{array}$ & $\begin{array}{c}4.9 \\
(4.6 \sim 5.5)\end{array}$ & $0.00 *$ & $\begin{array}{c}244 \\
(238 \sim 248)\end{array}$ & $\begin{array}{c}6.77 \\
(6.48 \sim 7.20)\end{array}$ & $0.00 *$ \\
\hline Potato & $\begin{array}{c}38.7 \\
(37.1 \sim 40.8)\end{array}$ & $\begin{array}{c}7.9 \\
(7.2 \sim 8.3)\end{array}$ & $0.00 *$ & $\begin{array}{c}402 \\
(397 \sim 409)\end{array}$ & $\begin{array}{c}5.29 \\
(4.69 \sim 6.18)\end{array}$ & $0.00 *$ \\
\hline Watermelon peels & $\begin{array}{c}20.3 \\
(18.2 \sim 23.9)\end{array}$ & $\begin{array}{c}6.6 \\
(5.9 \sim 7.1)\end{array}$ & $0.00 *$ & $\begin{array}{c}601 \\
(586 \sim 626)\end{array}$ & $\begin{array}{c}3.48 \\
(3.26 \sim 3.69)\end{array}$ & $0.00 *$ \\
\hline
\end{tabular}

Data are mean values of three replicates. The values given in parentheses show the range from minimum to maximum. $*$ means the observed difference is significant $(p<0.05)$. 


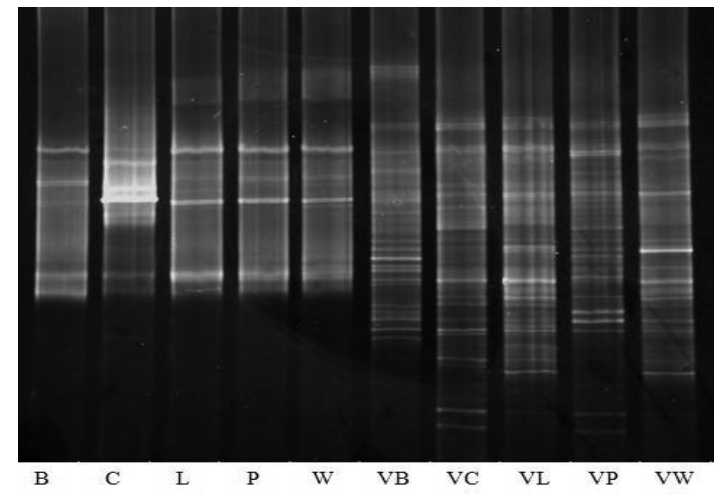

Fig. 2 DGGE Image of bacterial 16S rDNA of the PCR products from controls and vermicomposts of all FVWs. B, $\mathrm{C}, \mathrm{L}, \mathrm{P}$ and $\mathrm{W}$ represent the controls, and VB, VC, VL, VP and VW represent the vermicomposts. The letters of $\mathrm{B}, \mathrm{C}$, $\mathrm{L}, \mathrm{P}$ and $\mathrm{W}$ mean banana peels, cabbage, lettuce, potato and watermelon peels, respectively

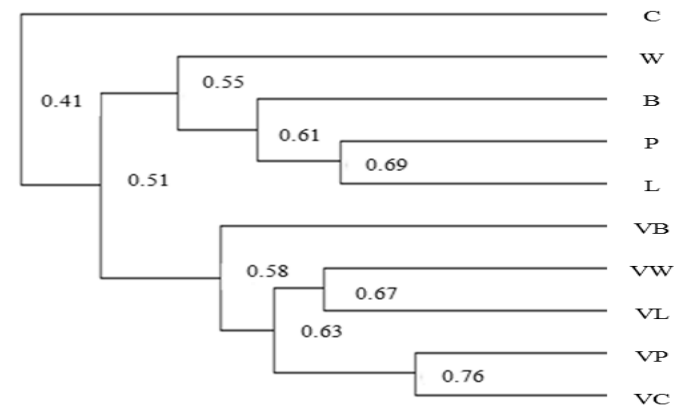

Fig. 3 Dendrogram of cluster analysis based on the band position on DGGE gel.

Figure 2 shows the PCR-DGGE gel of the 16S rDNA genes from bacterial communities of the control and vermicomposting samples. It was apparent that they displayed different profiles. The band numbers of control samples were significantly lower than those of vermicomposts. To better understand the difference in DGGE profiles, UPGMA was used to establish a dendrogram describing pattern similarities. UPGMA analysis of this DGGE showed that all vermicomposts clustered into a clear group, whereas the control treatments exhibited no obvious group. It was seen from Figure 3 that the five subsamples collected from the vermicomposts had a degree of similarity > $58 \%$, which was higher than that $(41 \%)$ associated with the control treatments. This result suggests that the vermicomposts were homogeneous materials that contained well specific bacterial community. The similar findings were reported in a previous study ${ }^{22)}$ which revealed that bacterial communities of vermicomposts had an average similarity coefficient of $71-80 \%$, in regards to the vermicomposting of different wastes by the same earthworm species. Compared to previous studies, although the pretreatment for fresh FVWs was omitted, the similar specific bacterial communities in all vermicomposts were still observed, which thus suggested the high degree of bio-stabilization and maturity in the end products was obtained though rapid vermicomposting. The highest similarity coefficient of control treatments was found in the potato and lettuce treatments, whereas the highest similarity coefficient of vermicomposting treatments was recorded in the potato and cabbage treatments. This result is probably ascribed to the selective effect of earthworms on bacteria during the earthworm-shaped bacterial process. Further investigations are required to elaborate this.

Table 4 Shannon index of the end vermicomposts and controls

\begin{tabular}{ccc}
\hline \multirow{2}{*}{ Waste type } & \multicolumn{2}{c}{ Shannon Index } \\
\cline { 2 - 3 } & Vermicompost & Control \\
\hline Banana peels & 3.36 & 2.38 \\
Cabbage & 3.49 & 2.20 \\
Lettuce & 3.33 & 2.15 \\
Potato & 3.32 & 2.24 \\
Watermelon peels & 3.16 & 2.79 \\
\hline
\end{tabular}

In order to gain insight into DGGE profiles, the structural diversity of the microbial community was also examined by the Shannon diversity index $(H)$. The vermicomposting treatments showed a higher $H$ value than the control treatments (Table 4), suggesting that a greater bacterial diversity existed in the earthworm-worked substrates. The vermicomposts from the cabbage treatment exhibited the highest $H$ value. The increase in the $H$ value was consistent with the result reported by other studies ${ }^{10-11)}$. Vivas et al, ${ }^{11)}$ demonstrated that the completed vermicast had larger bacterial population and functional diversities than the original and composted olive-mill wastes, with increased $H$ values calculated using DGGE banding patterns. The increased microbial communities in the vermicomposts are explained by the indirect priming effect produced from mucus, undigested materials and fresh cast, and direct gut selective effect of earthworms ${ }^{21)}$. The difference in microbial community among different vermicomposts was probably attributed to the different food quality. As reported by Knapp et $\mathrm{al}^{23)}$ the gut and cast microbiota were strongly influenced by the food source ingested, and the specific fingerprinting of microbial communities was highly relied on the type of substrate used. 


\section{CONCLUSIONS}

Experimental data provided a sound basis that vermicomposting using vermicompost as vermibedding was a suitable technology for recycling of fresh fruit and vegetable wastes. The maximum nutrient content of total nitrogen and total phosphorus was obtained in the cabbage and watermelon peels treatment, respectively. E. foetida exhibited higher growth rate and greater cocoon production in all the vermicomposting treatments. In addition, vermicomposts showed an increased microbial activity, bacterial number and community, which presumably reflected the bio-stabilization, and thus suggested the potential of being used as the bio-fertilizers for agriculture. The differences in physiochemical properties and bacterial profiles of vermicomposts clearly indicated that the quality of vermicomposts were highly dependent on the properties of the initial substrates.

ACKNOWLEDGEMENTS: The authors wish to thank professor Koji Kageyama in Gifu University for providing the Gel Doc 2000 System (Bio-Rad) used in the experiment.

\section{REFERENCE}

1) Garg P. Gupta A. and Satya S.: Vermicomposting of different types of waste using Eisenia foetida: A comparative study. Biores. Technol., Vol., 97, No. 3, pp. 391-395, 2006.

2) Aira M. Monroy F. and Domínguez J.: Earthworms strongly modify microbial biomass and activity triggering enzymatic activities during vermicomposting independently of the application rates of pig slurry. Sci.Total Environ., Vol., 385, No. 1-3, pp. 252-261, 2007.

3) Tajbakhsh J., et al: Recycling of spent mushroom compost using earthworms Eisenia foetida and Eisenia Andrei. The Environmentalist, Vol., 28, No. 4, pp. 476-482, 2008.

4) Mainoo N.O.K., et al: Pilot-scale vermicomposting of pineapple wastes with earthworms native to Accra, Ghana. Biores. Technol., Vol., 100, No. 23, pp. 5872-5875, 2009.

5) Fernández-Gómez M.J., et al: Continuous-feeding vermicomposting as a recycling management method to revalue tomato-fruit wastes from greenhouse crop. Waste Manage., Vol., 30, No. 12, pp. 2461-2469, 2010.

6) Gómez-Brandón, M., et al: Short-term stabilization of grape marc through earthworms. J. Hazard. Mater., Vol., 187, No. 1-3, pp. 291-295, 2011.

7) Fernández-Gómez M.J. Romero E. and Nogales R.: Feasibility of vermicomposting for vegetable greenhouse waste recycling. Biores. Technol., Vol., 101, No. 24, pp. 9654-9660, 2010.

8) Garg V.K. and Gupta R.: Optimization of cow dung spiked pre-consumer processing vegetable waste for vermicomposting using Eisenia foetida. Ecotoxic. and Environ. Safety, Vol., 74, No. 1, pp.19-24, 2011.

9) Suthar S.: Vermicomposting of vegetable-market solid waste using Eisenia fetida: Impact of bulking material on earthworm growth and decomposition rate. Ecol. Eng., Vol.,
35, No. 5, pp. 914-920, 2009.

10) Sen B. and Chandra T.S.: Do earthworms affect dynamics of functional response and genetics structure of microbial community in a lab-scale composting system. Biores. Technol., Vol., 100, No. 2, pp. 804-811, 2009.

11) Vivas A., et al: Assessing the impact of composting and vermicomposting on bacterial community size and structure, and microbial functional diversity of an olive-mill waste. Biores. Technol., Vol., 100, No. 3, pp. 1319-1326, 2009.

12) Paul J.A. Karmegam N. and Daniel T.: Municipal solid waste (MSW) vermicomposting with an epigeic earthworm, Perionyx ceylanensis Mich. Biores. Technol., Vol., 102, No. 12, pp. 6769-6773, 2011

13) Raphael K. and Velmourougane K.: Chemical and microbiological changes during vermicomposting of coffee pulp using exotic (Eudrilus eugeniae) and native earthworm (Perionyx ceylanesis) species. Biodegrad. Vol., 22, No. 3, pp. 497-507, 2011.

14) Pedersen J.C. and Hendriksen, N.B.: Effect of passage through the intestinal tract of detrivore earthworms (Lumbricus spp.) on the number of selected gram-negative and total bacteria. Biol. Fertil. Soils, Vol., 16, No. 3, pp. 227-232, 1993.

15) Kaviraj and Sharma S.: Municipal solid waste management through vermicomposting employing exotic and local species of earthworms. Biores. Technol., Vol., 90, No. 2, pp. 169-173, 2003.

16) Suthar S.: Pilot scale vermireactors for sewage sludge stabilization and metal remediation process: comparison with small-scale vermireactors. Ecol. Eng., Vol., 36, No. 5, 703-712, 2010.

17) Hobson A.M. Frederickson J. and Dise N.B.: $\mathrm{CH}_{4}$ and $\mathrm{N}_{2} \mathrm{O}$ from mechanically turned windrow and vermicomposting systems following in-vessel pretreatment. Waste Manag., Vol., 25, No. 4, pp. 345-352, 2005.

18) Morais F.M.C. and Queda C.A.C.: Study of storage influence on evolution of stability and maturity properties of MSW composts. In: Proceeding of the Fourth International Conference of ORBIT Association on Biological Processing of Organics: Advances for a Sustainable Society Part II Perth, Australia. 2003.

19) Aira M., Monroy F. and Domínguez J.: $\mathrm{C}$ to $\mathrm{N}$ ratio strongly affects population structure of Eisenia fetida in vermicomposting systems. Eur. J. Soil Biol., Vol., 42, No. supplement 1, pp.127-131, 2006.

20) Gunadi B. and Edwards C.A.: The effects of multiple applications of different organic wastes on the growth, fecundity and survival of Eisenia fetida (Savigny) (Lumbricidae). Pedobiologia, Vol., 47, No. 4, pp. 321-329, 2003.

21) Bernand L., et al: Endogeic earthworms shape bacterial functional communities and affect organic matter mineralization in a tropical soil. The ISME Journal, Vol., 6, No. pp. 213-222, 2012

22) Fernández-Gómez M.J., et al: Use of DGGE and COMPOCHIP for investigating bacterial communities of various vermicomposts produced from different wastes under dissimilar conditions. Sci. Total Environ., Vol., 414, No. 1, pp. 664-671.2012.

23) Knapp B.A., et al: Diet-related composition of the gut microbiota of Lumbricus rubellus as revealed by a molecular fingerprinting technique and cloning. Soil boil. Biochem., Vol., 41, No. 11, pp. 2299-2307, 2009 